\title{
The Effectiveness of Zakat in Reducing Poverty Incident: An Analysis in Kelantan, Malaysia
}

\author{
Ahmad Fahme Mohd Ali ${ }^{1}$, Zakariah Abd. Rashid ${ }^{2}$, Fuadah Johari ${ }^{1}$ \& Muhammad Ridhwan Ab. Aziz ${ }^{1}$ \\ ${ }^{1}$ Faculty of Economics and Muamalat, Universiti Sains Islam Malaysia (USIM), Nilai, Negeri Sembilan, \\ Malaysia \\ ${ }^{2}$ Malaysia Institute of Economic Research (MIER), Malaysia \\ Correspondence: Fuadah Johari, Faculty of Economics and Muamalat, Universiti Sains Islam Malaysia (USIM), \\ 71800 Nilai, Negeri Sembilan, Malaysia. E-mail: fuadah@usim.edu.my
}

Received: October 3, 2014 Accepted: November 17, 2014 Online Published: July 6, 2015

doi:10.5539/ass.v11n21p355 URL: http://dx.doi.org/10.5539/ass.v11n21p355

\begin{abstract}
This study attempts to examine the effectiveness of monthly zakat distribution as a mechanism to poverty reduction in the state of Kelantan. The target population of this study is the masakin (poor) and fuqara (hardcore poor) (Note 1) categories of the Kelantan Islamic Religious Department (MAIK) (Note 2) zakat recipients. Simple Random sampling procedure is applied to collect primary data related to zakat recipients from the poor and hardcore poor category of ten districts of Kelantan. The effects of zakat distribution on poverty are analyzed within the context of burden of poverty; specifically in terms of incidence, intensity and severity of poverty. These are examined using four major indices of poverty, which include the Headcount Index, Average Poverty Gap, Income Gap and Sen Index. Results revealed that zakat distribution reduces poverty incidence, reduces the extent of poverty and lessens the severity of poverty. Further, the current zakat distribution in Kelantan only gives a small effect on increasing the income of the poor. Hence, by locating the perfect amount of zakat distribution to eliminate poverty and to offer alternative zakat distribution model is the best way in reducing the income inequality and maximization of social welfare.
\end{abstract}

Keywords: Zakat distribution, poverty alleviation, poverty measures, Kelantan, Malaysia

JEL Classification: I13, O01

\section{Introduction}

The degree of poverty can be measured at the national level by observing the percentage of the population living under national poverty lines. The usual measurement is by using US\$1 and US\$2 (at 1993 Purchasing Power Parity terms) at reference poverty lines (Note 3$)$. It is estimated that 20 percent (1.2 billion) of the people in the world live on US\$1 a day and 46.7 percent (2.8 billion) of them live on \$2 a day (World Bank, 2001, p. 3). The corresponding percentages of poverty for International Development Bank (IDB) member countries indicate that a relatively large percentage of the populations of these countries are poor although the world economy has grown intensively.

In addition, Islam had brought a method on solving the problem of poverty. Islam makes it obligatory on every Muslim to pay a certain "tax", called Zakat, on their accumulated wealth. The money collected from this Zakat is distributed among the hardcore poor (Fuqara) and poor (Masakin). One of the most important principles of Islam is that all things belong to Allah S.W.T, and that wealth is therefore held by human beings in trust. The wealth is purified by setting aside a proportion for those in need, and, like the pruning of plants, this cutting back balances and encourages new growth in our wealth.

\section{Zakat and Poverty Alleviation}

Zakat is one of the five fundamental obligations of Islam. It is an obligatory form of worship (Ibadah) prescribed by Allah s.w.t. Allah commanded in the Qur'an:

“... so establish Salat and give Zakat, and hold fast to Allah ..."

(Al-Qur'an 22:78) 
The institutions of zakat are among several instruments instituted by Islam to combat and enhance welfare in the society. Zakat helps generate a flow of funds and at the same time increase the consumption of the poor and needy. The word zakat means growth, cleanness and purity in Arabic (Ibn Faris, 1998). The Qur'an mentions the word zakat 30 times and at three places it appears as being commanded by God (Allah s.w.t). Zakat is often called sadaqah in the Qur'an. The importance of zakat as an obligation on Muslims is also emphasized in many sayings of the Prophet Muhammad (pbuh). The importance of zakat may be established from a saying of the Prophet (pbuh) in which he indicates that refusing to pay it signify a rebellion against the Islamic State (Mujahid, 2007). Hence, zakat can be considered as an essential form of worship and spiritual purification.

In Kelantan, the collection of zakat is increasing from time to time. Thus, in this case, the opportunity of zakat as a method in reducing poverty is high. Zakat funds could be used to create a pull of funds which can be used in financing development activities which in future can replace government expenditures. For example from the year 2000 until 2013, zakat collection has increase from MYR 15.65 million to MYR 40.62 millions. This has shown on how much does zakat funds will creates more chances in reducing and eliminating the poverty in Kelantan.

\section{Problem Statement}

Zakat is one of the most important aspects in Islamic Economic System. One positive economic effect of zakat is it increases the money supply which consequent increases the demand for goods and services (Note 4) (Ishak \& Ismail, 2007). However many studies in Malaysia illustrate that zakat management reported a negative perception from the zakat payers on the management on zakat funds especially in term of distribution (Dahan, 1998; Sanep et al., 2006; Syukri, 2006; Abdul Halim et al., 2008). The objective of zakat is to assist and rehabilitate the poor and needy (Shirazi, 1996). Thus, the zakat management agency as the trustee for managing the collection and distribution of zakat has to assist in the process of growth and development of the Muslim community. They must ensure that zakat can fulfill the basic needs of the poor in the community and contributes toward a fair and just distribution and circulation of wealth in a society. Though, the effectiveness of zakat collection and distribution mainly depends on the good governance of zakat institution (Wahid \& Kader, 2010). If the zakat institution cannot be addressed properly, it could raise negative impact on the future development of the zakat institution.

\section{Literature Review}

According to Ahmed (2002) and Kahf (2004), the implementation of zakat can provide a micro financing to the poor. Zakat can be given out to the poor for consumption purposes to avoid diversion of funds from production. The combination of micro financing and zakat funds will make it easier for the poor to break out of the poverty cycle. To him, zakat is a redistribution measure while the roots of poverty in Muslim countries lie in productivity and level of economic development. Thus, any discussion of poverty eradication in the context of the Muslim countries must focus on increasing the diameter of the cake rather than distributing a small one. Monzer Khaf (2004) put it on the limitations of the zakat proceeds, hence suggested for the expansion of the zakat base.

Syed Othman Al-Habsyi (1994) explained that zakat can create demand that is one of the most important components in calculating Gross Domestic Product (GDP). The distribution of zakat will create ability for them to increase their capability to purchase. It is obvious that the fuqara (poor) and masakin (needy) did not have high demand power due to their low and insufficient income to support their needs. So their preference of using things among them is higher than rich people. Because of that, zakat can assist them by increasing their purchasing power. Any growth in demand obviously will accelerate to higher production for goods.

Saiful Azhar Rosly, (2008) explained that zakat plays an important role in poverty eradication and income redistribution of the Muslim people which is a critical component of public finance in Islam. Zakat administration in essence deals with the collection of zakat from zakat payers and distribution of zakat to the 8 recipients (Asnafs). He explained that the increasing number of shareholdings by Muslims in business corporations as well as companies using the Islamic label such as Islamic banks and takaful companies has provide strong basis for a systematic and efficient zakat system of collection and distribution.

S. M. Ali Akkas, (2006) revealed that the strength of zakat as a poverty alleviation tool depends on how much of the prevailing poverty gaps would be financed by zakat proceeds. The strength can be measured by portion of poverty gap that zakat can finance at rural and urban areas. This rural-urban segregation does not have any legal implication but it provides insights on the effect of interventions pursued on regional basis. The information received may help preparing policies which will encourages resources to be transferred wherever these would be of best use. It is quite evident that from his study on poverty alleviation in Bangladesh, zakat collected from rural area can cover only 14.8 percent of the rural poverty gap in 1997 . The coverage rises over time and becomes 
24.7 percent in 2005 . Per capita urban zakat receipts covers $67 \%$ of the urban poverty gap and it increases up to 84.3 percent by the year 2005 . The extremely low coverage of poverty gap by rural zakat receipts shows severity of rural poverty compared to urban poverty and the limitation of any poverty alleviation strategy solely based on rural zakat. This warrants for mitigation strategy with the necessary condition that the intervention package must be rural biased. Further it also must ensure that the net transfer of resources primarily comes from the rich to poor and equally from urban to rural

M. Kabir Hassan and Juanyed Masrur Khan (2007) estimate the impact of zakat funds on the annual development plan of Bangladesh. The zakat funds can increase the taxation potential of the government through the improvement of productivity, employment and output. Further, the implementation of zakat in Bangladesh has several potential effects on government budgets such as relieving budget categories targeted for poverty alleviation for other budgetary need, increase the potential of taxation through the improvement of productivity, employment and output. Additional the zakat collection can be used by the government as an important economic policy tools for country's development.

Ataul Huq (1993) in his study on development and distribution in Islam highlighted that out of eight beneficiaries of zakat collection, six are for direct benefit of the poor and needy. Thus, zakat can play a very significant role in the redistribution of income in the society which is performed by the Muslim obligation, who recognized their inborn rights to survival in this world. His study further explained the economic impact of zakat from the macro stand points which are, incentives to produce, to invest, to save, to consume and to work. If zakat can be accepted as an economy-wide type of redistribution mechanism of transferring resources from the rich to the poor, then it will provide the best tool for transfer mechanism in the society.

Dimas Bagus Wiranata Kusuma and Raditya Sukmana (2010) study about the power of zakat in poverty alleviation and found out that zakat can give impact in terms of consumption variable and investment variable. Thus, the more zakat disbursed to the recipient, the more in increasing the amount of aggregate consumption created into economy. In spite of in Islamic economic system, zakat payer will transfer their excess income or wealth to zakat recipient which indirectly will promote the higher propensity to consume of zakat recipient. For the zakat payer side, they will reduce the consumption, and turn into saving/investment activities.

Income support provided by zakat fund would increase the money supply in circulation and improve the economic gap between poor and rich group. Johari, F (2004), Patmawati (2006), Rahisam (2010), Mohd Ali, AF (2011) \& Ahmed Fahme et al., (2013) show in their studies that zakat has significant impact in bringing positive effect towards improving the income distribution of the poor and needy. Thus, this study tries to measure the level of the effectiveness of zakat in reducing poverty incident in complimenting and enrich the previous study and literatures in Kelantan, Malaysia.

\section{Research Methodology}

This study will explore the contribution of zakat distribution in reducing the burden of poverty which will cover the poverty incidence, the intensity, and the severity of poverty among the fuqara and masakin. To measure the poverty incidence, this study will use the head-count index $(H)$ that shows the proportion of the poor households among the total households. The extent or depth of poverty is measured by using the mean income gap $\left(\mathrm{P}_{1}\right)$ and poverty-gap ratio (I). The severity of poverty, which includes the income distribution among the poor, will be measured by the Sen's index of poverty $\left(\mathrm{P}_{2}\right)$. The Sen's index is a comprehensive poverty measure, which incorporates the information on the number of poor $(H)$, the extent of poverty, measured by income gap $(I)$, and the Gini coefficient $(G)$, as an indicator of income distribution among the poor.

The poverty measures will be estimated on both data sets on the basis of national poverty line (PLI) at MYR 740, to see the effect of zakat distribution on poverty to the society. Those who receive income below the PLI is considered poor (masakin) while half from PLI will be consider as hardcore poor (fuqara). Further, by measuring the income it is an easy to read and easy to compare method. Income measures provide a clearly understood measure of welfare and its determinants. It provides a well-defined unit of analysis that is comparable across households living in different localities. That is the underlying distribution is in terms of monetary units, which has its own merits for comparing poverty as well as inequality. The monetary approach provides a deeper accurate measure of the current standard of living and exhibits continuity in the welfare indicator.

This study involves testing two sets of data. By using four most popular indexes in measuring the poverty; Household-count ratio, Income Gap, Poverty Gap and Sen Index, and the primary data survey based on Zakat Recipient Survey, we first test the income data, before the amount of zakat distribution is included in the household income $f\left(y_{1}\right)$. Following Kakwani (1986), Shirazi (1994), Jehle (1994), Patmawati (2006) and Mohd Ali, AF (2011) Johari F et al. (2014) \& (2015) the amount of the zakat transfer is subtracted from the income of 
the household in order to get the first set of income distribution. This result will provide us information about the burden of poverty incidence, extent and severity before zakat distribution.

Second, we tested the income data after the zakat distribution by using the same poverty index measurement $f\left(y_{2}\right)$. This second results will provide us the information of the poverty incidence, extent and severity after zakat was distribution. To see the effect of zakat towards reducing the poverty, the result from both tests will be compared. The difference between these results will provides us with information about the effectiveness of zakat in reducing the burden of poverty incidence, extent and severity in Kelantan. The poverty measures will be estimated on both data sets on the basis of national poverty line at MYR 740, to see the effect of zakat distribution on poverty to the society.

The headcount ratio $(H)$ is used to answer the first question of how many are poor. This ratio is called the head-count (household-count).

$$
H=\frac{q}{n}
$$

This measure is also known as the poverty incidence that it gives the percentage of the poor households among the total households.

The extent or the depth of poverty is measured by using the poverty gap, and income gap of the society.

$$
\begin{aligned}
& P_{1}=\sum_{i=1}^{q} g_{i} \\
& I=\sum_{i=\in S(z)} g_{i} / q z
\end{aligned}
$$

The mean income gap and poverty gap ratio will be estimated on both $f\left(y_{1}\right)$, and $f\left(y_{2}\right)$ income distribution. The severity of poverty will be measured in this study by using the Sen's Index.

$$
P_{2}=H[I+(1-I) G]
$$

The severity of poverty will be estimated on both data sets of $Y_{1}$ and $Y_{2}$ frequency household income distribution. The value of $\mathrm{P}_{2}$ lies in the closed interval $[0,1]$, with $\mathrm{P}_{2}=0$ if everyone has income greater than $z$, and $\mathrm{P}_{2}=1$ if everyone has zero income. $\mathrm{G}$ will be equal to zero $(G=0)$ when all the poor has the same income.

The diagnosis of poverty will be described in terms of the following characteristics of households;

i) Gender of the household head,

ii) Location by districts

iii) The age of the households head,

v) Household size

Table 1. Number of respondent based on districts area (2008)

\begin{tabular}{ccccc}
\hline District & Mukim & Respondent & Total Fuqara and Masakin & Percent $(\%)$ \\
\hline Bachok & 8 & 55 & 836 & 5.7 \\
Gua Musang & 3 & 36 & 150 & 23.3 \\
Jeli & 3 & 35 & 276 & 12.6 \\
Kota Bharu & 15 & 90 & 1939 & 4.6 \\
Kuala Krai & 3 & 40 & 142 & 28.1 \\
Machang & 6 & 40 & 760 & 7.8 \\
Pasir Mas & 10 & 60 & 672 & 7.1 \\
Pasir Putih & 8 & 38 & 207 & 16.9 \\
Tanah Merah & 3 & 42 & 602 & 6.9 \\
Tumpat & 7 & 481 & 126 & 28.5 \\
TOTAL & & & 5710 & 8.4 \\
\hline
\end{tabular}

Source: Research questionnaire 
Respondents for this study are selected from the list of MAIK zakat recipients of the fuqara and masakin (poor and needy) category, which is the target population. The first criteria for the respondent selection are those who have been receiving the zakat from MAIK more than one year. With the cooperation and assistant of the zakat officer of MAIK, the survey encompassed the entire ten districts of Kelantan. Sample of the study are 481 households (8.4 percent) of the total population of 5710 fuqara and masakin (poor and needy) households in Kelantan. For each mukim, 6 respondents were randomly selected from the list of zakat recipient of MAIK. Initially, a number of 481 questionnaires cum interviews carried out in all ten districts in Kelantan. Table 1 illustrates the number of respondent based on districts area.

In order to collect the primary data, a set of questionnaire is used as a survey module for this study. The fieldwork was carried out from January 2009 to May 2009 and it is done by face to face interviews with the respondents based on the questionnaires In order to answer those previous questions, the questionnaire is divided into three parts. The first part (Part A) is emphasizing on information regarding the background and basic information of the head of households and their household's members. The second part (Part B) is used to gather information on the size and sources of monthly household's income. The third part (Part C) is used to gather the type and amount of assistance that is received by the households from poverty eradication agencies. Pilot test was carried out in Pasir Putih district prior to the actual fieldwork, with the following objectives:

i. To ensure that the questions are understood and answerable by the respondent.

ii. To estimate the time needed to interview one respondent. This is important in order to estimate the time and financial budget of the actual fieldwork so that the right number of field enumerators will be employed.

iii. To estimate possibilities of 'non-responsive' respondents, in order to decide the right sample size and be prepared to overcome such problem.

\section{Result}

Table 2 presents the impact of zakat on households' monthly income of the fuqara and masakin categories zakat recipients. Figure 1 shows the graphical presentation of the income impact.

Table 2. Kelantan: changes in monthly household income with and without Zakat distribution by district (MYR)

\begin{tabular}{ccccc}
\hline District & $\begin{array}{c}\text { Income without } \\
\text { zakat (MYR) }\end{array}$ & $\begin{array}{c}\text { Income with zakat } \\
(\text { MYR })\end{array}$ & $\begin{array}{c}\text { Amount of zakat } \\
\text { distribution (MYR) } \\
(1)=(2)-(1)\end{array}$ & $\begin{array}{c}\text { Percentage of zakat to the } \\
\text { total income }(\%) \\
(4)=[(3) /(2)] \times 100\end{array}$ \\
\hline KELANTAN & 191918 & 264938 & $73020(100 \%)$ & 27.56 \\
Bachok & 24443 & 33593 & $9150(12.6 \%)$ & 27.23 \\
Gua Musang & 15050 & 20730 & $5680(7.8 \%)$ & 27.39 \\
Jeli & 13750 & 19300 & $5550(7.2 \%)$ & 28.75 \\
Kota Bharu & 33930 & 48680 & $14750(18.3 \%)$ & 30.29 \\
Kuala Krai & 16605 & 22815 & $6210(8.6 \%)$ & 27.21 \\
Machang & 15500 & 21820 & $6320(8.2 \%)$ & 28.96 \\
Pasir Mas & 22190 & 30990 & $8800(11.7 \%)$ & 28.39 \\
Pasir Putih & 18810 & 25060 & $6250(9.4 \%)$ & 25.94 \\
Tanah Merah & 14000 & 18750 & $4750(7 \%)$ & 23.96 \\
Tumpat & 17640 & 23200 & $5560(8.7 \%)$ & \\
\hline
\end{tabular}

Source: Research questionnaire

Table 2 shows the difference between the household monthly income before and after zakat distribution. From the table we can see that monthly household income had increased with the zakat distribution. The amount and percentage of zakat distribution varies among the districts. Tanah Merah received the lowest amount of zakat distribution with only 7 percent while Kota Bharu is enjoying the highest with 18.3 percent. This gives us a brief picture of zakat allocation which mostly centered in Kota Bharu because this district has the highest amount of fuqara and masakin. Overall, zakat distribution contributes 27.56 percent to the total income of the fuqara and masakin in Kelantan. By districts, the percentage of contribution ranges in between 23percent to 30 percent. Minimum contribution to the total income is received by Tumpat (23.96 percent), while Kota Bharu is enjoying the highest (30.29 percent). 


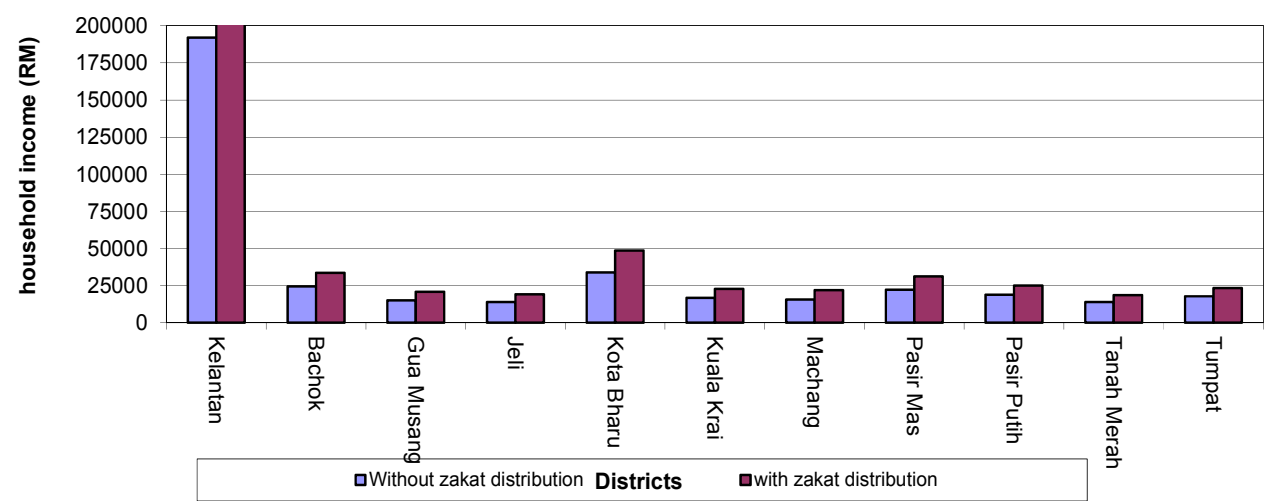

Source: Research questionnaire

Figure 1. Kelantan: changes in monthly household income (MYR) with and without the Zakat distribution (per family)

The result of zakat distribution to the poor are analyzed by using four major poverty indices of Household-count ratio $(\mathrm{H})$, mean income gap $\left(\mathrm{P}_{1}\right)$, poverty gap ratio $(I)$ and Sen index $\left(\mathrm{P}_{2}\right)$ to reveal three major problems of: how many are poor, the extent or depth of poverty, and the severity of poverty. Table 3 presents a summary of the poverty measures of this study.

Table 3. Kelantan poverty measures: before and after zakat distribution (by districts) in the households' income

\begin{tabular}{ccccccccc}
\hline & \multicolumn{3}{c}{ Before Zakat Distribution } & \multicolumn{5}{c}{ After Zakat Distribution } \\
\cline { 2 - 8 } Districts & $\mathrm{H}_{1}$ & $\mathrm{P}_{1}$ (MYR) & $\mathrm{I}_{1}$ & $\mathrm{P}_{2}$ & $\mathrm{H}_{2}$ & $\mathrm{P}_{1}(\mathrm{MYR})$ & $\mathrm{I}_{2}$ & $\mathrm{P}_{2}$ \\
\hline KELANTAN & 0.90 & 341 & 0.46 & 0.54 & 0.83 & 211 & 0.28 & 0.36 \\
Bachok & 0.94 & 319 & 0.43 & 0.55 & 0.80 & 242 & 0.32 & 0.36 \\
Gua Musang & 0.91 & 324 & 0.43 & 0.54 & 0.77 & 194 & 0.26 & 0.32 \\
Jeli & 0.88 & 347 & 0.47 & 0.53 & 0.85 & 217 & 0.29 & 0.36 \\
Kota Bharu & 0.96 & 363 & 0.49 & 0.60 & 0.91 & 233 & 0.31 & 0.41 \\
Kuala Krai & 0.87 & 324 & 0.43 & 0.50 & 0.86 & 195 & 0.26 & 0.33 \\
Machang & 0.92 & 352 & 0.47 & 0.57 & 0.82 & 223 & 0.30 & 0.36 \\
Pasir Mas & 0.91 & 370 & 0.50 & 0.58 & 0.83 & 240 & 0.32 & 0.38 \\
Pasir Putih & 0.93 & 348 & 0.47 & 0.54 & 0.85 & 218 & 0.29 & 0.35 \\
Tanah Merah & 0.91 & 340 & 0.45 & 0.54 & 0.86 & 210 & 0.28 & 0.35 \\
Tumpat & 0.86 & 320 & 0.43 & 0.49 & 0.80 & 190 & 0.25 & 0.32 \\
\hline
\end{tabular}

Note: H: Household-count ratio (poverty incidence)

$\mathrm{P}_{1}$ : Mean Income Gap; I: Poverty Gap Ratio; $\mathrm{P}_{2}$ : Sen index of poverty

From Table 3, the highest reduction in poverty incidence occurred in Bachok and Gua Musang with 0.14 while Kuala Krai enjoys the lowest reduction in poverty incidence with 0.01 in Kelantan. This proven that zakat distribution in that Bachok and Gua Musang is more effective than other districts in Kelantan mostly in Kuala Krai. As a whole, the highest poverty incidence in Kelantan is in the district of Kota Bharu with $96 \%$ rate of poverty before the zakat distribution.

After the zakat distribution, Kota Bharu still has the highest poverty incidence, even though the poverty rate has reduced to $91 \%$. However, the household-count ratio is the very basic measure of poverty, which gives us the percentage of the households below poverty line of RM 740. With identical poverty rates, the two poor subpopulations may have very different average income levels. It is completely insensitive to the extent of the poverty shortfall per person. From the incidence results, it shows that poverty is concentrated more on the urban area (Kota Bharu and Pasir Mas). Most of poverty happens in this area because of the migrating people who comes in this area and hopping to find job and income. But due to lack of skills and knowledge, it is hard for them to get any job and income and further from poor, they had become a hard core poor and become a homeless. 
The extent of poverty is highest in Pasir Mas with mean income gap of RM 370 and 0.50 poverty gap ratio before zakat was distributed. Next, Kota Bharu is the second highest district of poverty extent before zakat distribution with average mean income gap of RM 363 and 0.49 poverty gap ratio, followed by Machang, Jeli and Pasir Putih have the average mean income gap of RM 352, RM 348, RM 347 respectively and 0.47 poverty gap ratio before zakat was distributed. Bachok has the lowest mean income gap and poverty gap ratio with RM 319 and 0.43 before the distribution of zakat.

After zakat was distributed, Bachok who has the lowest amount of poverty extent has become the highest amount of poverty extent although it has reduced from RM 319 for mean income gap and 0.43 for income gap to RM 242 and 0.32. Pasir Mas becomes the second highest district of poverty extent with RM 239 and 0.32 and followed by Kota Bharu with RM 232 and 0.31. Tumpat has the lowest of poverty extent with RM 193 and 0.25 .

Results on poverty severity $\left(\mathrm{P}_{2}\right)$ reveals that the income distribution among the people in Pasir Mas is distinctly unequal and their consumption level is extremely low although the number of people below poverty line in that area is lower than the number of poor people in some other areas but in terms of severity of poverty, it is the second highest compare to other areas. For example, the incident of poverty in Pasir Mas (0.91) is lower than Kota Bharu (0.96), Bachok (0.94), Machang (0.92) and Pasir Putih (0.93), but in term of severity of poverty, their severity is the second highest in Kelantan with 0.58 . This also indicates that the severity of poverty can be high in the low poverty incidence area. From Table 6.10, we also noticed that Gua Musang has the highest reduction in poverty severity with 0.22 followed by Machang (0.21) and Pasir Mas (0.20). It means that zakat distribution in that district has improved the income of the worst poor and needy in that area.

\section{Poverty Map}

A poverty map is a data set that provides information about the spatial distribution of poverty within a country, which allows the visualization of the incidence and magnitude of poverty across space. Based on four selected characteristic of the households which are; gender of the head of the households, location of area by districts, age of the head of households, and size of households, Table 4 presents poverty map of Kelantan, before and after zakat distribution. The poverty map shows that zakat distribution has improved the poverty incidence, the extent of poverty, and the severity of poverty of the affected households. However, the trends of poverty in terms of the most affected area do not change with the existence of zakat distribution. In other words, zakat distribution improved the income of all the households concerned, but the improvement is not enough to overtake their poverty burdens, in all selected characteristics of the households.

The poverty map reveals that poverty is concentrated among the female households head. Based on district, poverty appears to be more apparent in Kota Bharu and Pasir Mas. Poverty is highest among the households' head belonging to the age of 25 to 40 . From the poverty map, we can see that zakat distribution did not reduced or give impact to the numbers of household with 1 to 3 members because this group has the highest amount of poverty incidence (1) before and after zakat distribution. But in term of mean income gap $\left(\mathrm{P}_{1}\right)$, poverty gap ratio (I) and severity, zakat distribution has given some positive contribution in reducing their burden of poverty. The poverty map also shows that poverty is prevalent among the households with 1 to 3 members, which normally applies to old folks/couple. It is observed from the map that the area with highest poverty incidence, also experiences the most severe form of poverty. From the table, we can see that those whose households with 10 and above enjoying the least poverty gap and exciding the Poverty Line Income (PLI) after zakat were distributed. It should be noted that although this group enjoys the highest zakat distribution, their income is still not enough to cover the whole family members compared to those who has less than 10 members in the family.

Table 4. Poverty map with and without zakat distribution (PLI= MYR 740)

\begin{tabular}{|c|c|c|c|c|c|c|c|c|}
\hline \multirow{3}{*}{$\begin{array}{l}\begin{array}{l}\text { Selected characteristics of } \\
\text { households }\end{array} \\
\text { 1) Gender of } \\
\text { households' } \\
\text { head }\end{array}$} & \multicolumn{2}{|c|}{ Poverty Incidence } & \multicolumn{2}{|c|}{ Mean Income Gap } & \multicolumn{2}{|c|}{ Poverty Gap Ratio } & \multicolumn{2}{|c|}{ Sen Index } \\
\hline & wOZ & WZ & woz & $\mathrm{WZ}$ & woz & $\mathrm{wZ}$ & wOZ & $\mathrm{WZ}$ \\
\hline & & & & & & & & \\
\hline Male & 0.86 & 0.80 & 316 & 187 & 0.42 & 0.25 & 0.50 & 0.32 \\
\hline Female & 0.93 & 0.80 & 373 & 244 & 0.50 & 0.32 & 0.59 & 0.39 \\
\hline 2) Districts & 0.94 & 0.80 & 319 & 242 & 0.43 & 0.32 & 0.55 & 0.38 \\
\hline Bachok & 0.91 & 0.77 & 324 & 194 & 0.44 & 0.26 & 0.54 & 0.33 \\
\hline Gua Musang & 0.88 & 0.85 & 347 & 218 & 0.47 & 0.29 & 0.53 & 0.36 \\
\hline Jeli & 0.96 & 0.91 & 363 & 232 & 0.49 & 0.31 & 0.60 & 0.42 \\
\hline Kota Bharu & 0.87 & 0.86 & 324 & 195 & 0.43 & 0.26 & 0.50 & 0.35 \\
\hline
\end{tabular}




\begin{tabular}{|c|c|c|c|c|c|c|c|c|}
\hline Kuala Krai & 0.92 & 0.80 & 352 & 223 & 0.47 & 0.30 & 0.57 & 0.37 \\
\hline Machang & 0.91 & 0.83 & 370 & 239 & 0.50 & 0.32 & 0.58 & 0.39 \\
\hline Pasir Mas & 0.93 & 0.85 & 348 & 217 & 0.47 & 0.29 & 0.54 & 0.35 \\
\hline Pasir Putih & 0.91 & 0.85 & 340 & 211 & 0.46 & 0.28 & 0.54 & 0.36 \\
\hline $\begin{array}{l}\text { Tanah Merah } \\
\text { Tumpat }\end{array}$ & 0.86 & 0.80 & 320 & 193 & 0.43 & 0.25 & 0.49 & 0.32 \\
\hline \multicolumn{9}{|c|}{$\begin{array}{l}\text { Tumpat } \\
\text { 3) Age households' } \\
\text { head }\end{array}$} \\
\hline $25-40$ & 0.97 & 0.93 & 405 & 275 & 0.54 & 0.37 & 0.64 & 0.46 \\
\hline $41-56$ & 0.85 & 0.73 & 312 & 182 & 0.42 & 0.24 & 0.49 & 0.29 \\
\hline $\begin{array}{l}57 \text { and } \\
\text { above }\end{array}$ & 0.88 & 0.73 & 380 & 252 & 0.51 & 0.33 & 0.57 & 0.34 \\
\hline \multicolumn{9}{|l|}{ 4) Household size } \\
\hline $1-3$ & 1 & 1 & 481 & 352 & 0.65 & 0.47 & 0.73 & 0.55 \\
\hline $4-6$ & 1 & 1 & 392 & 260 & 0.53 & 0.35 & 0.61 & 0.43 \\
\hline $7-9$ & 0.90 & 0.75 & 277 & 148 & 0.37 & 0.19 & 0.46 & 0.25 \\
\hline $\begin{array}{l}10 \text { and } \\
\text { above }\end{array}$ & 0.43 & 0.25 & 37.1 & -92 & 0.05 & -0.12 & 0.08 & 0.003 \\
\hline
\end{tabular}

Note: woz- without zakat distribution; wz - with zakat distribution

Income per individual for the selected characteristics of household as shown in Table 5 also shows an improvement to the current income after zakat was distributed. For gender household's head, male has the highest income before and after zakat distribution, MYR 72.54 per month and MYR 2.43 per day before zakat distribution and it increase to MYR 104.36 per month and MYR 3.48 per day after zakat distribution. Income per individual for Kelantan is MYR 65.93 per month and MYR 2.20 per day before zakat distribution and it also increase to MYR 93.30 per month and MYR 3.11 per day after zakat was distributed. For districts, Tanah Merah has the highest income before zakat distribution with MYR 79.97 per month and MYR 2.67 per day while Jeli has the lowest income per month (MYR 58.69) and per day (MYR 1.96). After zakat distribution, Tanah Merah still has the highest income with MYR 109.89 per month and MYR 3.66 per day while Pasir Putih has become the lowest income per month (MYR 80.10) and per day (MYR 2.67). For age of the household's head, those who are aged between 25 to 40 has the highest income per month with MYR 74.07 and MYR 2.47 per day before the zakat distribution while those who aged 41 to 56 has the lowest income with MYR 62.46 per month and MYR 2.47 per day. After zakat distribution those who aged 25 to 40 still maintain the highest income with MYR 106.17 per month and MYR 3.54 per day and those who aged 41 to 56 still has the lowest income with MYR 85.17 per month and MYR 2.84 per day. For the household size, before zakat distribution, those who with 1 to 3 household size has the highest income per month with MYR 89.84 and MYR 2.99 per day while family with 7 to 9 household has the lowest income with MYR 52.04 per month and MYR 1.73 per day. After zakat distribution, the family with 1 to 3 household sizes still has the highest income per month with MYR 137.39 and MYR 4.58 per day while family with 7 to 9 household still has the lowest income with MYR 67.04 per month and MYR 2.23 per day.

Table 5. Income per individual before and after zakat distribution

\begin{tabular}{lllll}
\hline \multirow{2}{*}{ Selected characteristics of households } & \multicolumn{3}{c}{ Before Zakat } & \multicolumn{2}{c}{ After Zakat } \\
\cline { 2 - 5 } & Per month (MYR) & Per day (MYR) & Per month (MYR) & Per day (MYR) \\
\hline 1) Gender of households' head & & & & 3.48 \\
Male & 72.54 & 2.43 & 104.36 & 2.75 \\
Female & 60.93 & 2.03 & 82.45 & 3.11 \\
\hline 2) Districts & & & & 2.81 \\
KELANTAN & 65.93 & 2.20 & 93.30 & 2.89 \\
Bachok & 63.22 & 2.10 & 84.29 & 2.73 \\
Gua Musang & 63.22 & 2.10 & 86.67 & 3.51 \\
Jeli & 58.69 & 1.96 & 81.86 & 2.74 \\
Kota Bharu & 73.86 & 2.46 & 105.32 & 3.30 \\
Kuala Krai & 59.28 & 1.98 & 82.22 & 2.97 \\
Machang & 69.88 & 2.33 & 98.99 & 2.67 \\
Pasir Mas & 63.16 & 2.11 & 89.11 & 3.66 \\
Pasir Putih & 58.74 & 1.96 & 80.10 & 109.89 \\
Tanah Merah & 79.97 & 2.67 & & \\
\hline
\end{tabular}




\begin{tabular}{lcccc}
\hline Tumpat & 63.88 & 2.13 & 87.51 & 2.92 \\
\hline 3) Age & & & & \\
$25-40$ & 74.07 & 2.47 & 106.17 & 3.54 \\
$41-56$ & 62.46 & 2.08 & 85.17 & 2.84 \\
57 and above & 62.90 & 2.10 & 90.44 & 3.01 \\
\hline 4) Household size & & & & \\
$1-3$ & 89.84 & 2.99 & 137.39 & 4.58 \\
$4-6$ & 57.95 & 1.93 & 79.93 & 2.66 \\
$7-9$ & 52.04 & 1.73 & 67.04 & 2.23 \\
10 and above & 62.38 & 2.08 & 73.95 & 2.46 \\
\hline
\end{tabular}

Source: Research Question

\section{Discussion}

Analysis on poverty in this study is based on poverty line income of MYR 740 has shown a positive result on poverty incidence, extent and severity of income due to zakat distribution. Zakat distribution in Kelantan has only give a small improvement in the mean income and poverty gap of the fuqara and masakin. Results on poverty analysis of this study seem to be encouraging. The results from the household-count ratio, the mean income gap, the poverty gap ratio and Sen's index measures suggest an improvement in income distribution after zakat is distributed. It means that this study has proven the positive contribution of zakat in reducing poverty.

This study has also identified that poverty is more serious on the urban area. Kota Bharu has the highest poverty incidence $(\mathrm{H})$ and poverty severity $\left(\mathrm{P}_{2}\right)$ while Pasir Mas has the highest mean income gap $\left(\mathrm{P}_{1}\right)$ and poverty gap ratio (I) before zakat was distributed and after zakat distribution. The highest amount of poverty incidence $(\mathrm{H})$ and Income Gap (I) is still in Kota Bharu and it also become the highest districts of poverty incidence while Bachok become the districts with the highest mean income gap $\left(\mathrm{P}_{1}\right)$.

A large scale of urbanization that has swelled the ranks of the urban poor in Kota Bharu is the main reason that contributes a large number of poverty in that urban area. The migration of rural low-income groups into the urban areas, the influx of the foreign workers and the results of increase in unemployment have contributed to the rise in poverty rates in that area while at the same time pressures the urban services, infrastructure and the environment. As a result, poverty, which has long been predominantly in a rural area, has become more urbanized. Low levels of education or skills, lack of employment opportunities, low wages, large family size and lack of basic amenities are among the factors that cause urban poverty.

The most important finding in his study is that although Kota Bharu received the highest zakat distribution among ten districts in Kelantan, it still maintains the worst poverty incidence, the extent of poverty, and experienced the worst severe effect of poverty after zakat distribution. This study also proves that high of poverty incidence, extent and severity, can also happen in developed area (i.e Kota Bharu) compared to underdeveloped area, as the case of Tumpat, for example. This situation implies that, even though it is a developed area, the number of poor people in Kota Bharu is high, compared to the number of poor people in Tumpat. Besides that, the results of this study show that the extent of poverty can be high in low poverty incidence area, as the case of Pasir Mas. This means that, even though the number of poor in Pasir Mas is small, but the poverty gap is high. In other words, the poor people in that area are receiving a lower income compared to other districts.

For the poverty gap and income gap that measures the shortfall of the income from the Poverty Line Index, the people in Pasir Mas has the worst shortfall among other districts in Kelantan. Although the incidence (quantity) in that area is not too bad (compared to Kota Bharu) but their gap (quality) is worse than Kota Bharu. It might be the case that people in Kota Bharu has a high poverty incidence but low poverty gap (when numerous members are just below the poverty line), while in Pasir Mas they have a low poverty incidence but a high poverty gap for those who are poor (when relatively few members are below the poverty line but with extremely low levels of income). Compared to herders, people in Kota Bharu has a higher risk of being in poverty, but the poverty is more severe in Pasir Mas. Further, the types of interventions needed to help the two groups are therefore likely to be different.

From the poverty map, it is noted that poverty is prevalent among the households with female households head. Most of the previous study about poverty agreed that female households head women have higher poverty rates than men in almost all societies (Casper et al., 1994). There are two main reasons poverty is more serious among female household head; 1) lower income due to lack of capability to work in a job that is dominantly by male, and 2) single mother who life with children. For a female headed household, finding a job that is suitable with 
their capability, skills and qualification will be hard mostly with the competition from male gender. Most company will preferred to pay for male gender for they have more strength and capability in doing various jobs. While this had left the female gender only one more choice, that is to involved in doing hard work such as working in security (i.e; Factory or school) and driver (i.e; bus driver) which is not all female gender is capable to do it. Having children in the household affects the likelihood of poverty in one definitional way. Since the poverty line is adjusted for household size, the presence of children in a household raises the income necessary for the household to escape poverty, and thus, income equal, single adults who live with children are more likely to be poor than those who live alone. Single mother are much more likely to live with children than single men, since women usually have custody of the children in cases of divorce or no marital births. Thus, even if single men and women had equal earnings, more of the women than the men would be in poverty by virtue of supporting children.

Poverty is also common among the households' head at the age of 25 to 40 . Normally, this group does not have the opportunity to go to school at their schooling age, consequently did not qualify for a better-paid job. Survey carried out suggests that most of the households with 1 to 3 members of households consist of an old couple, who are no longer economically productive has the highest poverty burden. The poverty map, shows where poverty is concentrated in Kelantan, and consequently which are the most affected group of poverty. Hence, it shows where zakat distribution might have the greatest effect on poverty. This can help the policymakers; like those in the Economic Planning Unit (EPU) and Majlis Agama Islam Kelantan (MAIK) to focus on efficient allocation of scarce zakat resources as well as reducing and eliminate poverty in Kelantan.

Result from monthly and daily income per individual shows that zakat distribution contributes in increasing the income which exceeding the daily poverty line (\$US 1.00) for about 40 percent of the district in Kelantan. While male household head, age of household head 41 to 56 and size of household 4 and above are still below this World Bank poverty line (Note 5). It is clear that zakat distribution based on household size is needed to bring the income of those who are still under this poverty line exceeded \$US 1.00 (Note 6) of income per day. Overall, the results of the previous poverty measures and the poverty map, shows where poverty is concentrated in Kelantan, and consequently which the most affected group of poverty is. Hence, it shows where zakat distribution might have the greatest effect on poverty. This can help the policymakers; like those in the Economic Planning Unit (EPU) and Majlis Agama Islam Kelantan (MAIK) to focus on efficient allocation of scarce zakat resources as well as reducing and eliminate poverty in Kelantan.

\section{Conclusion}

Zakat distribution has proven its effectiveness in improving per individual monthly and daily income for zakat recipient in Kelantan. This effectiveness is proven with the improvement of monthly and daily income for all selected characteristics after the zakat distribution but still it's way too far from reaching the World standard of MYR 6.20 income per individual per day. Analysis on poverty in this study has shown a positive result on poverty incidence, extent and severity of income due to zakat distribution. Zakat distribution in Kelantan has only give a small improvement in the mean income and poverty gap of the fuqara and masakin. Results on poverty analysis of this study seem to be encouraging. The results from the household-count ratio, the mean income gap, the poverty gap ratio and Sen's index measures suggest an improvement in income distribution after zakat is distributed. It means that this study has proven the positive contribution of zakat in reducing poverty.

\section{Reference}

Ab. Rahman, A. S. (1995). Eradication of Poverty in the State of Kelantan, West Malaysia from an Islamic Perspectives: An Ethical Dimension (Ph.D Thesis). University of Wales, Lampeter.

Abdul Rahman, R., \& Ahmad, S. (2010). Pengukuran Keberkesanan Agihan Zakat: Perspektif Maqasid Al-Syariah. Paper presented at Seventh International Conference - The Tawhidi Epistemology: Zakat and Waqf Economy.

Ahmad Fahme A., Ab Aziz, R., Ibrahim, F., Zaleha, N., \& Johari, F. (2013). Impact of Zakat Distribution on Poor and Needy Recipients: An Analysis in Kelantan, Malaysia. Australian Journal of Basic and Applied Sciences, 7(13), 177-182.

Ahmad, S., \& Wahid, H. (2004). Kesan Prestasi Agihan Oleh Institusi Formal Ke Atas Kepatuhan Membayar Zakat. pkukmweb.ukm.my -hairun

Ahmad, S., Wahid, H., \& Mohamad, A. (2006). Penswastaan Institusi Zakat dan Kesannya Terhadap Pembayaran Secara Formal di Malaysia. International Journal of Management Studies, 13(2), 175-196.

Ahmed, H. (2004). Role of zakat and awqaf in poverty alleviation. Islamic Development Bank, Islamic Research 
and Training Institute.

Ahmed, H. (2008). Zakat, Macroeconomic Policies, and Poverty Alleviation: Lessons from Simulations on Bangladesh. Journal of Islamic Economics, Banking and Finance, 4(2).

Akkas, S. A. (2006). Women in Development, Islamic Perspective: Compilation of Seminar Papers. Islamic Economics Research Bureau.

Ali Akkas, S. M. (2006). An Islamic Alternative to Poverty Alleviation: The "PARSHI" (Neighbourhood) Model. International Seminar on Islamic Alternative to Poverty Alleviation: Zakat, Awkaf and Microfinance.

Ali, M., \& Fahme, A. (2011). Role of Zakat in Poverty Reduction in Kelantan, Malaysia (Masters thesis). Universiti Putra Malaysia.

Anand, S. (1973). The Size Distribution of Income in Malaysia (Part 1). World Bank: Development Research Center.

Anand, S., \& Kanbur, S. M. R. (1993). Inequality And Development: A Critique. Journal of Development economics, 41(1), 19-43.

Atkinson, A. B. (1987). On The Measurement of Poverty. Econometrica, 55(4), 749-764.

Atkinson, A. B. (2003). Income Inequality in OECD Countries: Data and Explanations. Institute for Economic Research, CESifo Economic Studies, 49(4), 479-513.

Aziz, U. A. (1964). Poverty and Rural Development in Malaysia. Kajian Ekonomi Malaysia, 1(1), 70-105.

Chaudhuri, S. (2003). Assessing vulnerability to poverty: concepts, empirical methods and illustrative examples. Department of Economics Columbia University.

Hassan, M. K., \& Khan, J. M. (2007). Zakat, External Debt and Poverty Reduction Strategy in Bangladesh. Journal of Economic Cooperation, 28(4), 1-38.

Heshmati, A. (2005). The Relationship between Income Inequality, Poverty, and Globalization. Research Paper No. 2005/37.

Huq, A. (1993). Development and Distribution in Islam. Petaling Jaya: Pelanduk Publications (M) Sdn. Bhd.

Ibrahim, P. (2006). Economic Role of Zakat in Reducing Income Inequality and Poverty in Selangor. PhD Thesis. Faculty of Economics and Management, Universiti Putra Malaysia.

Jehle, G. A. (1994). Zakat and Inequality: Some Evidence from Pakistan. Review of Income and Wealth, 40(2).

Johari, F. (2004). Keberkesanan zakat dalam mengatasi masalah kemiskinan di negeri Melaka. Unpublished Master Dissertation. Kuala Lumpur: Akademi pengajian Islam, University Malaya.

Johari, F., \& Ibrahim, P. (2007). Zakat Sebagai Motivasi Pembangunan Ekonomi Umat Islam. In d. Kamarudin et al. (Eds.), Islam Di Malaysia Pasca Kemerdekaan. Bangi: Jabatan Usuluddin dan Falsafah, Fakulti Pengajian Islam, Universiti Kebangsaan Malaysia, 77-95.

Johari, F., Ab Aziz, M. R., \& Ali, A. F. M. (2014). The role of zakat in reducing poverty and income inequality among new convert (muallaf) in Selangor, Malaysia. Online Journal of Research in Islamic Studies, 1(3), 43-56.

Johari, F., Ali, A. F. M., \& Ab Aziz, M. R. (2015). The Role of Zakat Distribution Among Muallaf (New Convert) In Reducing Poverty In Selangor, Malaysia. İktisat Politikası Araştırmaları Dergisi, 2(1), 39-56.

Kahf, M. (2004). Shariah and Historical Aspects of Zakah and Awqaf. Background, paper prepared for Islamic Research and Training Institute, Islamic Development Bank.

Kakwani, N. (1980). On A Class of Poverty Measures. Econometrica, 48(2), 437-446.

Kelantan, M. A. I. (1994). Fatwa Sistem Agihan Zakat Negeri Kelantan. Jawatankuasa Perunding Hukum Syarak (FATWA) Negeri Kelantan Darul Naim,

Kusuma, D. B. W., \& Sukmana, R. (2010). The Power of Zakat in Poverty Alleviation. Seventh International Conference - The Tawhidi Epistemology: Zakat and Waqf Economy.

Latif, M. D. A. (2001). Pendekatan Kepada Cara Pengagihan Dana zakat yang Dinamik Sesuai dengan Suasana Semasa. Dalam Nik Mustapha Nik Hassan (penyt). Kaedah Pengagihan Dana Zakat Satu Perspektif Islam. Kuala Lumpur: IKIM.

Lubis, M., Yaacob, N. I., Omar, Y., Dahlan, A., \& Rahman, A. (2011, April). Enhancement of zakat distribution 
management system: case study in Malaysia. In International Management Conference 2011 Proceedings (pp. 1-10). University Sultan Zainal Abidin.

Malaysia. (1965). First Malaysia Plan 1966-1970. Kuala Lumpur: Government Printers.

Malaysia. (1971). Second Malaysia Plan 1971-1975. Kuala Lumpur: government Printers.

Malaysia. (1976) Third Malaysia Plan 1976-1980. Kuala Lumpur: Government Printers.

Malaysia. (1981) Fourth Malaysia Plan 1981-1985. Kuala Lumpur: Government Printers.

Malaysia. (1986). Fifth Malaysia Plan 1986-1990. Kuala Lumpur: Government Printers.

Malaysia. (1991). Sixth Malaysia Plan 1991-1995. Kuala Lumpur: Government Printers.

Malaysia. (1991). The Second Outline Perspective Plan. Kuala Lumpur: Government Printers.

Malaysia. (1996). Seventh Malaysia Plan 1996-2000. Kuala Lumpur: Government Printers.

Malaysia. (2001). Eighth Malaysia Plan 2001-2005. Kuala Lumpur: Government Printers.

Malaysia. (2001). The Third Outline Perspective Plan 2001-2010: Kuala Lumpur: Government Printers.

Malaysia. (2007). Laporan Ekonomi Negeri Kelantan 2007. Economic Planning Unit of Malaysia.

Mannan, M. A. (1986). Islamic economics: Theory and practice. Cambridge: Hodder and Stroughton.

Metwally, M. M. (1983). Fiscal Policy in Islamic Economy. In Z. Ahmed, M. Iqbal, \& M. F. Khan (Eds.), Fiscal Policy and Resource Allocation in Islam (pp. 59-81). Jeddah, Saudi Arabia: International Centre for Research in Economics, King Abdul Aziz University.

Minujin, A., \& Delamonica, E. (2005). Incidence, Depth and Severity of Children in Poverty. Division of Policy and Planning of UNICEF.

Mohd Nor, M. A., Wahid, H., \& Mohd Nor, N. G. (2003). Kesedaran Membayar Zakat Pendapatan Kakitangan Profesional: Kajian Kes di UKM. Dalam Zulkefly Abd Karim et. Al (penyt). Prosiding Seminar Kebangsaan Dasar Awam dalam Era Globalisasi. Kuala Lumpur: Univision Press Sdn Bhd.

Mujahid, A. M. (2007). Zakat and Fasting (p. 2). Retrieved from http://www.islambasics.com

Onagun, I. A., Johari, F., \& Muhmmad, H. A. (2014). Managing Immediate Action for Women and Poverty Reduction in Nigeria: An Explanation from the Generic Theory. Asian Journal of Management Sciences \& Education, 3(1).

Ramli, R. M., Ahmad, S., Wahid, H., \& Harun, F. M. (2011). Understanding asnaf attitude: Malaysia's experience in quest for an effective zakat distribution programme. In International Zakat Conference: Sustainable Zakat Development in the Poverty Alleviation and Improvement of Welfare of the Ummah.

Ramli, R., \& Ibrahim, P. (2010). Kesan Agihan Zakat dalam Membasmi Kemiskinan dan Ketidakseimbanngan Agihan Pendapatan di Negeri Sembilan. Persidangan Kebangsaan Ekonomi Malaysia ke-V (PERKEM). 15-17 October 2010, organized by Pusat Pengajian Ekonomi Fakulti Ekonomi \& Pengurusan, Universiti Kebangsaan Malaysia (UKM).

Rosly, S. A. (2008). Malaysia and Islamic Economics. International Center for Education in Islamic Finance (INCEIF), (Paper presented at the Hadhari Economics Roundtable Conference, Universiti Kebangsaan Malaysia, 25th November 2008, MALAYSIA)

Salleh, M. S. (2006). Lokalisasi Pengagihan Zakat: satu Cadangan Teoritis. dalam Hailani \& Abdul Ghafar (penyt). Zakat: Pensyariatan, Perekonomian \& Perundangan. Bangi: Penerbit Universiti Kebangsaan Malaysia 85 Abdul Halim Mohd Noor, Rozman Hj Md Yusof \& Ahmad Che Yaakob (2008). Performance indicators model for zakat institution. Jurnal Pengurusan JAWHAR : 70-84

Shimeles, A., \& Thoenen, R. (1992). A Methodological Note On Measuring Poverty. Economic Research and Training Institute, IDB, 19.

Shimeles, A., \& Thoenen, R. (2005). Poverty Profiles: A Methodological Note on Measuring Poverty. Poverty and Social Policy Team Economic and Social Policy Division.

Shirazi, N. S. (1994). Targeting, Coverage and Contribution of Zakat to Households' Income: The Case of Pakistan. Journal of Economic Coorperation Among Islamic Country, 14, 4-5.

Shirazi, N. S. (1996). Targeting, Coverage and Contributing of Zakat to Household's Income: The Case of Pakistan. Journal of Economic Cooperation Among Islamic Countries, 17. 
Syed Othman, Al-H. (1988). Peranan Zakat Dalam Membantu Pembangunan Ekonomi Negara. Konvensyen Zakat Kebangsaan 1988. Pusat Islam, Universiti Sains Malaysia, Bahagian Zakat, Majlis Agama Islam Pulau Pinang, Jabatan Hasil Dalam Negeri Pulau Pinang, 5-6 November 1988.

Syed Othman, Al-H. (1992). Konsep Pengagihan Saksama (dalam Ahmad Sobri Jaafar dan Abdul Razak Chik (penyelenggara) Prosiding Kursus Ekonomi Islam: Asas, Falsafah dan Aplikasi, Kedah: UUM.

Syed Othman, Al-H. (2001). Zakat Perniagaan: Potensi Dan Cabaran Di Era Ekonomi Baru. Seminar Zakat Dan Cukai Pendapatan. Sekretariat Pusat Zakat Negeri- Negeri (SPZ) and Jabatan Kemajuan Islam Malaysia (JAKIM) dengan kerjasama AFTAAS Consulting Sdn, Renaissance Palm Garden Hotel, Putrajaya, 18 September 2001.

The Asian Development Bank. (2001). Initiating Draft of Poverty Assessment: The Philippines.

Wahid, H., \& Kader, R. A. (2010). Localization of Malaysian Zakat Distribution: Perceptions of Amil and Zakat Recipients. In d. A. Ghafar et al. (Eds.), Proceedings of Seventh International Conference (pp. 461-484). The Tawhidi Epistemology: Zakat and Waqf Economy.

Wahid, H., Ahmad, S., \& Mohd Nor, M. A. (2004). Kesan Bantuan Zakat Terhadap Kualiti Hidup Asnaf Fakir dan Miskin. The Journal of Muamalat and Islamic Finance Research, 1(1), 151-166.

Wahid, H., Ahmad, S., \& Nor, M. A. M. (2004). Kesan Bantuan Zakat Terhadap Kualiti Hidup: Kajian Kes Asnaf Fakir dan Miskin ("The effect of zakat aid on the quality of life: the case of the poor and needy recipients"). The Journal of Muamalat \& Islamic Finance Research, 1, 151-66.

Wess, H. (2002). Reorganizing Social Welfare among Muslims: Islamic Voluntarism and Other Forms of Communal Support in Northern Ghana. Journal of Religion in Africa, 32(1).

World Bank. (2000). World Development Report 2000-2001: Attacking Poverty. World Bank Group.

Zakaria, Ab. R. (2007). Pengurusan Zakat Kontemporari. Jurnal Jabatan Wakaf, Zakat dan Haji, 1(1), 11-19.

Zakaria, M. (2014). The Influence of Human Needs in the Perspective of Maqasid al-Syari'ah on Zakat Distribution Effectiveness. Asian Social Science, 10(3), 165-173. http://dx.doi.org/10.5539/ass.v10n3p165

\section{Notes}

Note 1. Masakin (poor) defined as those who receive income below the Poverty Line Income while fuqara' (hard core poor) means those who receive income half the from PLI.

Note 2. Majlis Agama Islam Kelantan

Note 3. The World Bank often uses $\$ 1$ a day for cross-country comparisons, which has since 1990 come to be regarded as providing the absolute minimum standard of living. See "Nature and Evolution of Poverty, 1998-2003" pg. 49.

Note 4. Zakat distribution is a transfer of money or fund from non poor to the poor. Thus it creates a money supply to the poor and increases their demand for goods and services.

Note 5. The World Bank often uses $\$ 1$ a day for cross-country comparisons, which has since 1990 come to be regarded as providing the absolute minimum standard of living. See "Nature and Evolution of Poverty, 1998-2003" pg. 49.

Note 6. 1 US\$ is RM 3.25 (for Mei, 2014)

\section{Copyrights}

Copyright for this article is retained by the author(s), with first publication rights granted to the journal.

This is an open-access article distributed under the terms and conditions of the Creative Commons Attribution license (http://creativecommons.org/licenses/by/3.0/). 